\title{
Diluted Earnings Per Share Overstatement Bias: Including Unrecognized Employee Compensation In Proceeds From Assumed Exercise Of Employee Stock Options Under The Treasury Stock Method
}

David T. Doran, Pennsylvania State University, Erie, USA

\begin{abstract}
Generally accepted accounting principles (GAAP) require firms to recognize compensation expense under the fair value method in the case of employee stock options. Straight line amortization of the option's grant date fair value must be recognized as expense over the service period which decreases the earnings per share numerator. For diluted earnings per share (EPS), GAAP requires using the treasury stock method, where proceeds from assumed stock option exercise is used to purchase treasury shares at the average for the period price. Exercise proceeds include the exercise price plus unrecognized future employee compensation. For profitable firms, exercise is assumed if dilutive - more shares are assumed issued than are reacquired for the treasury which increases the diluted EPS denominator. These requirements are consistent across US GAAP and International Financial Reporting Standards. This paper tests whether including unrecognized employee compensation in proceeds from the assumed exercise of employee stock options under the treasury stock method is appropriate. A simple multi period model that assumes a risk free environment with complete certainty is applied. This study contributes to the literature by demonstrating that future unrecognized employee compensation should not be included in proceeds from the assumed exercise of stock options under the treasury stock method. Doing so consistently causes diluted EPS overstatement, and in certain instances causes assumed exercise of "in the money" options to be antidilutive, which results in complete exclusion from the diluted EPS calculation. This research extends the employee stock option work of Doran (2005 and 2008) that found: 1) Compensation expense recognized over the employee service period should equal the periodic annuity amount that provides the option's grant date fair value, and 2) Treasury shares should be assumed purchased at the higher end of period stock price.
\end{abstract}

Keywords: Diluted Earnings per Share Overstatement Bias; Employee Stock Options; Treasury Stock Method

\section{INTRODUCTION}

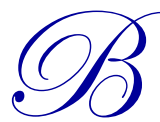

oth the Financial Accounting Standards Board (FASB) and International Financial Reporting Standards (IFRS) require application of the fair value method in determining compensation expense for employee stock options. These standards are uniform in mandating that this "fair value" amount be determined with reference to the instrument granted and disallow using the value of employee services received. Explaining their position IFRS states, "Because of the difficulty of measuring directly the value of services received, the entity shall measure the fair value of the services received by reference to the fair value of the equity instruments granted....". The FASB using similar language states, "A share based payment transaction with employees shall be

\footnotetext{
${ }^{1}$ International Financial Reporting Standard No. 2, Paragraph 11.
} 
based upon the fair value .... of the equity instruments issued". ${ }^{2}$ Both FASB and IFRS generally accepted accounting principles (GAAP) require straight-line recognition of the equity instruments' computed fair value over the period of employee service. Doran (2008) shows that doing so understates compensation expense, and that the correct amount should instead be based upon the higher computed annuity amount, given the fair value of the equity instrument and the period of employee service. Since compensation expense reduces the numerator in earnings per share (EPS) calculations, understatement of compensation expense is shown to overstate the reported EPS.

In the case of outstanding stock options, the diluted EPS denominator must include any "incremental shares" calculated using the treasury stock method. The treasury stock method assumes options are exercised (and shares issued) at the beginning of the period (or grant date if granted during the period). The proceeds from this assumed share issuance are assumed used to purchase shares of the firm's stock for the treasury. Profitable firms assume exercise if the reacquisition price per share exceeds proceeds per share. In this situation, more shares are assumed issued than are assumed purchased for the treasury. These incremental shares increase the denominator, with resulting EPS dilution. Both the FASB and IFRS require that treasury shares be assumed repurchased at the average for the period price. ${ }^{3}$ Doran (2005 and 2008) demonstrates that treasury shares should be assumed purchased at the higher year end price and assuming purchase at the lower average for the period price causes diluted EPS overstatement.

\section{PURPOSE OF STUDY AND METHODOLOGY}

When applying the treasury stock method in the case of employee stock options, the proceeds from assumed exercise include not only the exercise price, but also any unrecognized future compensation. ${ }^{4}$ The requirement to include unrecognized compensation in the assumed proceeds is consistent across FASB ${ }^{5}$ and IFRS ${ }^{6}$ GAAP. This inclusion increases the number of shares assumed purchased for the treasury, which decreases the diluted EPS denominator, increasing reported diluted EPS. Here, diluted EPS is computed both with and without inclusion of unrecognized compensation in the proceeds from the assumed exercise of employee stock options. The results indicate that proceeds from the assumed exercise of employee stock options should not include unrecognized compensation, and doing so causes diluted EPS overstatement.

A simple multi-period model that assumes complete certainty is developed. The fair value of employee compensation is given, and the complete certainty assumption indicates that the employee and the firm should be economically indifferent to various compensation schemes (cash transfer, debt issue, stock transfer, or stock option grant). Given this economic equivalence, the true amount of EPS is "known" and should be consistently observed regardless of the compensation scheme assumed. Initially EPS is calculated under the cash, debt issue, and stock transfer scenarios. For each of these scenarios, calculated EPS amounts are found to equal the "known" EPS. This indicates that GAAP is appropriate in accounting for cash, debt, and stock transfers.

Diluted EPS is then calculated assuming the stock option scenario. If current GAAP is appropriate, EPS observed in the case of the stock option scenario should equal the "known" (correct) amounts. The fair value method is applied and any treasury stock is assumed acquired at the average for the period price using proceeds that include both the exercise price and the unrecognized compensation. The results indicate diluted EPS is overstated when unrecognized compensation is included in proceeds from assumed exercise of employee stock options. Correct diluted EPS amounts are observed when assumed proceeds exclude unrecognized compensation; and consistent with Doran (2005 and 2008), compensation expense is computed as an annuity amount, and treasury

\footnotetext{
${ }^{2}$ FASB Accounting Standards Codification 718-10-30-2 (originally Statement of Financial Accounting Standards (SFAS) No. 123, Revised (December 2004) Paragraph 7).

${ }^{3}$ FASB Accounting Standards Codification 260-10-45-23 (originally Statement of Financial Accounting Standards No. 128 (February 1997) paragraph 107), and International Accounting Standard No. 33, Paragraph 45.

${ }^{4}$ In the case of unqualified stock options, the proceeds also include adjustment for excess tax benefit. Since this study assumes exercise price of options equal to market value at the grant date (incentive stock options, discussed later), there are no tax consequences for the firm.

${ }^{5}$ FASB, Accounting Standards Codification, 260-10-45-29 (originally Statement of Financial Accounting Standards No. 128 (February 1997) Paragraph 21).

${ }^{6}$ International Accounting Standard No. 33 "Earnings per Share" Paragraph 47A.
}

1658 Copyright by author(s) Creative Commons License CC-BY

$2013 \underline{\text { The Clute Institute }}$ 
shares are assumed purchased at the higher end of period price. Current GAAP understates the amount of employee compensation expense and assumes too many shares are purchased for the treasury. This combination results in an overstatement of the EPS numerator and an understatement of the EPS denominator, both of which contribute to overstatement of diluted EPS when accounting for employee stock options under current GAAP.

\section{MODEL $^{7}$}

The analysis is based upon various compensation schemes for a firm's employee who renders services worth $\$ 1$ million due at the beginning of each of four consecutive years (x1, x2, $x 3$, and $\mathrm{x} 4$ ). This simple four period model includes the following additional assumptions:

1. There is no risk, and all entities earn an available $10 \%$ risk free rate of return.

2. There are no dividends, taxes, or transaction costs.

3. With the exception of stock based compensation, accrual basis amounts are consistent with related cash flows.

4. The book value of the firm is $\$ 220$ million at $1 / 1 / x 1$.

5. The firm has 10 million shares of stock outstanding at $1 / 1 / \mathrm{x} 1$ and the market value per share is $\$ 22$, the total market value of the firm is $\$ 220$ million.

6. If a stock option is used as compensation, it is fully transferable, vests and is exercisable at $12 / 31 / x 4$; also if employment terminates prior to the 4 year option term, vesting occurs at that time and the options must exercised immediately.

Under the assumptions of the model, all participants are certain that the market value of the stock in one year (1/1/x2) will be $\$ 24.20$ per share, $\$ 26.62$ on $1 / 1 / x 3$, and $\$ 29.282$ on $1 / 1 / x 4$. With that being the case, the firm (and employee) should be indifferent to compensation packages of:

a. $\quad$ Cash payments of $\$ 1$ million on $1 / 1 / \mathrm{x} 1,1 / 1 / \mathrm{x} 2,1 / 1 / \mathrm{x} 3$, and $1 / 1 / \mathrm{x} 4$,

b. Issuing one year $\$ 1$ million $10 \%$ notes on $1 / 1 / \mathrm{x} 1,1 / 1 / \mathrm{x} 2,1 / 1 / \mathrm{x} 3$, and $1 / 1 / \mathrm{x} 4$,

c. Transferring 45,454.54.... shares of stock on 1/1/x1 (@ $\$ 22 / \mathrm{sh}=\$ 1,000,000), 41,322.31 \ldots .$. shares of stock on 1/1/x2 (@ \$24.20/sh=\$1,000,000),37,565.74.... shares of stock on 1/1/x3 (@ \$26.62/sh=\$1,000,000), and $34,150.67 \ldots .$. shares of stock on 1/1/x4 (@ \$29.282/sh $=\$ 1,000,000)$, or

d. Granting the employee an option to purchase 500,000 shares of the firm's stock for $\$ 22.00$ per share with a term of 4 years (see assumption 6 above). ${ }^{8}$

Given the model's assumptions and economic equivalence of the cash payment vs. debt issue vs. stock transfer vs. stock option compensation scenarios, the computed earnings per share should be consistent across these alternatives. Computed EPS should increase by ten percent per year and these predetermined known amounts are: $\$ 2.20$ for $\mathrm{x} 1, \$ 2.42$ for $\mathrm{x} 2, \$ 2.662$ for $\mathrm{x} 3$ and $\$ 2.9282$ for $\mathrm{x} 4$.

\footnotetext{
${ }_{8}^{7}$ The model is derived from Doran (2008).

${ }^{8}$ The simplifying assumption of no taxes is more appropriate in the case of an incentive stock option plan (ISOP) because there would be no tax consequences for the granting firm. One requirement for ISOP treatment is that the exercise price be minimally set at the grant date fair value of the stock. Setting the exercise price at the grant date fair value of the stock results in granting the employee an option to buy 500k shares at $\$ 22$ per share.
} 
Table 1: Diluted EPS Assuming: Cash, Debt, or Stock Issuance as Compensation

\begin{tabular}{|c|c|c|c|c|}
\hline \multicolumn{5}{|l|}{ Panel A: Cash Compensation } \\
\hline & Year $x 1$ & Year $\mathbf{2}$ & Year x3 & Year $x 4$ \\
\hline Income before Compensation expense & $\$ 23,000,000$ & $\$ 25,200,000$ & $\$ 27,620,000$ & $\$ 30,282,000$ \\
\hline Compensation Exp. & $1,000,000$ & $1,000,000$ & $1,000,000$ & $1,000,000$ \\
\hline Net Income & $\$ 22,000,000$ & $\$ 24,200,000$ & $\$ 26,620,000$ & $\$ 29,282,000$ \\
\hline Shares outstanding & $10,000,000$ & $10,000,000$ & $10,000,000$ & $10,000,000$ \\
\hline EPS & $\$ 2.20$ & $\$ 2.42$ & $\$ 2.662$ & $\$ 2.9282$ \\
\hline \multicolumn{5}{|l|}{ Panel B: Debt Issuance Compensation } \\
\hline & Year x1 & Year $\mathbf{x} 2$ & Year x3 & Year $x 4$ \\
\hline Income before Interest and Compensation expense & $\$ 23,100,000$ & $\$ 25,300,000$ & $\$ 27,720,000$ & $\$ 30,382,000$ \\
\hline Interest Exp. & 100,000 & 100,000 & 100,000 & 100,000 \\
\hline Compensation Exp. & $1,000,000$ & $1,000,000$ & $1,000,000$ & $1,000,000$ \\
\hline Net Income & $\$ 22,000,000$ & $\$ 24,200,000$ & $\$ 26,620,000$ & $\$ 29,282,000$ \\
\hline Shares outstanding & $10,000,000$ & $10,000,000$ & $10,000,000$ & $10,000,000$ \\
\hline EPS & $\$ 2.20$ & $\$ 2.42$ & $\$ 2.662$ & $\$ 2.9282$ \\
\hline \multicolumn{5}{|l|}{ Panel C: Stock Issuance Compensation } \\
\hline & Year $x 1$ & Year x2 & Year x3 & Year $x 4$ \\
\hline Income before Compensation expense & $\$ 23,100,000$ & $\$ 25,410,000$ & $\$ 27,951,000$ & $\$ 30,746,100$ \\
\hline Compensation Exp. & $1,000,000$ & $1,000,000$ & $1,000,000$ & $1,000,000$ \\
\hline Net Income & $\$ 22,100,000$ & $\$ 24,410,000$ & $\$ 26,951,000$ & $\$ 29,746,100$ \\
\hline Shares outstanding & $10,045,454.55$ & $10,086,776.86$ & $10,124,342.6$ & $10,158,493.27$ \\
\hline EPS & $\$ 2.20$ & $\$ 2.42$ & $\$ 2.662$ & $\$ 2.9282$ \\
\hline
\end{tabular}

\section{RESULTS}

Table 1 provides the GAAP based calculation of EPS in the case of cash compensation (Panel A), debt issue (Panel B), and stock transfer (Panel C). They each provide the true "known" amounts of earnings per share. These are the correct performance measures given the model assumptions of a requisite $10 \%$ return and the $1 / 1 / \mathrm{x} 1$ fair value of the stock of $\$ 22$ per share. Note that the income before compensation and interest expense is initially higher under the debt issue scenario than under the cash payment scenario. This is attributed to the additional cash ( $\$ 1$ million) being retained by the firm at the beginning of each year and invested to earn the risk free rate of $10 \%$. However, the recognition of interest expense results in these scenarios having the same net income measures. Net income is higher in the case of the stock transfer scenario. This is caused by the additional cash retention (similar to the debt issue scenario), but without reduction for interest expense. Note however that this numerator increase is offset by a proportionate denominator increase due to shares issued, such that the "known" amount of EPS consistently results.

Table 2 illustrates computations of diluted EPS in the case of employee compensation through stock options. Panel A illustrates diluted EPS amounts computed under GAAP and Panel B illustrates the adaptations necessary to arrive at the correct known amounts of diluted EPS. 
Given the assumptions of the model the fair value of the option is determined by ${ }^{9}$ :

$\mathrm{O}=\mathrm{M}-\mathrm{E} /(1+\mathrm{i})^{\mathrm{n}}$

where:

$\mathrm{O}=$ option value on grant date,

$\mathrm{M}=$ market price of stock on grant date $=\$ 22 /$ share,

$\mathrm{E}=$ exercise price $=\$ 22 /$ share,

$\mathrm{i}=$ risk free interest rate $=10 \%$, and

$\mathrm{n}=$ number of years until option expires $=4$ years.

Solving the option pricing formula results in each option share valued at $\$ 6.9737 \ldots$, and the entire 500,000 optioned shares valued at $\$ 3,486,852 .{ }^{10}$ SFAS No. $123(\mathrm{R})$ and IFRS No. 2 require this estimated value of the equity instruments be used to determine the total employee compensation cost which is expensed on a straight-line basis over the service period. GAAP therefore requires recognizing $\$ 871,713$ of employee compensation expense in each of the four years $(\mathrm{x} 1, \mathrm{x} 2, \mathrm{x} 3$, and $\mathrm{x} 4)$. The worth of the employee compensation assumed in this model is known with certainty ( $\$ 1$ million per year), and the amount of compensation expense recognized under GAAP is understated by $\$ 128,287$ each year ( $\$ 1$ million - \$871,713). Doran (2008) demonstrates that the known amount of compensation expense can be calculated by treating the employee service appropriately - like an annuity provided each period. Applying the assumptions of this model, the calculated amount of 4 annuity due payments discounted at $10 \%$ providing a present value of $\$ 3,486,852$ is $\$ 1$ million per year. This known amount is included in Table 2 (Panel B) as the correct amount of employee compensation used for purposes of calculating diluted EPS.

Table 2 (Panel A) applies the treasury stock method required under GAAP. Consistent with US GAAP and IFRS, the proceeds include the exercise price plus unrecognized employee compensation, and number of treasury shares purchased is determined using the average for the year market value of the stock. Consistent with the example provided in the Accounting Standards Codification, the unrecognized compensation for each year's diluted EPS is calculated by adding together the beginning and end of year unrecognized compensation amounts together, and then dividing by $2 .{ }^{11}$ Using this prescribed method, year $\mathrm{x} 1$ unrecognized compensation equals $\$ 3,050,995.50$ $(\$ 3,486,852+\$ 2,615,139) / 2)$, year $x 2$ equals $\$ 2,179,282.50(\$ 2,615,139+\$ 1,743,426) / 2$, year 3 equals $\$ 1,307,569.50$ $(\$ 1,743,426+\$ 71,713) / 2$, and year $\mathrm{x} 4$ equals $\$ 435,856.50(\$ 871,713+\$ 0) / 2$. The average market value of the firm's stock is the arithmetic average of the beginning and ending values per share each year. For year 1, beginning and ending values are $\$ 22$ and $\$ 24.20$, respectively, which equals $\$ 23.10$ per share average market price. The average market price for years 2,3 , and four, respectively are $\$ 25.41, \$ 27.951$, and $\$ 30.7461$. Doran (2005 and 2008) shows that under these simple model assumptions, correct EPS amounts are derived when shares are assumed purchased for the treasury at the higher year-end market price. Contrary to GAAP, Table 2 (Panel B) assumes: that the exercise proceeds completely exclude unrecognized employee compensation, and treasury shares are purchased at the higher year end price.

As Table 2 (Panel A) indicates, the number of incremental shares included in the diluted EPS denominator is consistently understated when the assumed exercise proceeds include unrecognized employee compensation. This is particularly obvious in years $\mathrm{x} 1$ and $\mathrm{x} 2$, where the effect of such inclusion causes total proceeds per share to exceed the assumed treasury purchase price per share ( $\$ 28.10$ vs. $\$ 23.10$ in $x 1$, and $\$ 26.36$ vs. $\$ 25.41$ in $x 2)$. Since assuming exercise would be anti-dilutive (decrease the denominator with no change in the numerator) in years $\mathrm{x} 1$ and $\mathrm{x} 2$, exercise of employee options is not assumed and diluted EPS is based upon the actual 10,000,000 shares outstanding. Stated differently, even though these options are "in the money" exercise would not be assumed for purposes of determining diluted EPS, and only basic EPS would be presented in the $\mathrm{x} 1$ and $\mathrm{x} 2$ income statements.

\footnotetext{
${ }^{9}$ See Nikolai (2010) pg. 795

${ }^{10}$ Discounting the future cash flows @ $10 \%$ results in a present value at $1 / 01 / x 1=\$ 3,486,852$ for each of the four compensation packages.

${ }^{11}$ See "Example 8: Application of the Treasury Stock method to Share Based Payment Arrangements", Accounting Standards Codification 260-10-55-69 through 260-10-55-70.
} 
Table 2: Diluted EPS Computation Assuming Stock Option Compensation

\begin{tabular}{|c|c|c|c|c|}
\hline $\begin{array}{l}\text { Panel A: Computation Un } \\
\text { Expense, Proceeds Include }\end{array}$ & $\begin{array}{l}\text { IP: Straight } \\
\text { snized Comp }\end{array}$ & $\begin{array}{l}\text { ognition of Op } \\
\text { and Treasury }\end{array}$ & $\begin{array}{l}\text { int Date Valu } \\
\text { rchased at A }\end{array}$ & $\begin{array}{l}\text { mpensation } \\
\text { ice }\end{array}$ \\
\hline & Year x1 & Year x2 & Year x3 & Year $x 4$ \\
\hline Inc. before comp. exp. & & & & \\
\hline Compensation exp. & $\$ 23,100,000$ & $\$ 25,410,000$ & $\$ 27,951,000$ & $\$ 30,746,100$ \\
\hline Net Income - Numerator & 871,713 & 871,713 & 871,713 & 871,713 \\
\hline & $\$ 22,228,287$ & $\$ 24,538,287$ & $\$ 27,079,287$ & $\$ 29,874,387$ \\
\hline Proceeds: & & & & \\
\hline Exercise cash & $\$ 11,000,000$ & $\$ 11,000,000$ & $\$ 11,000,000$ & $\$ 11,000,000$ \\
\hline Unrecognized comp. & $3,050,996$ & $2,179,283$ & $1,307,570$ & 435,757 \\
\hline Total proceeds & $\overline{\$ 14,050,996}$ & $\$ 13,179,283$ & $\$ 12,307,570$ & $\$ \$ 11,435,757$ \\
\hline Total proceeds/sh. & $\$ 28.10$ & $\$ 26.36$ & $\$ 24.615$ & $\$ 22.8717$ \\
\hline Treasury purchase price/sh. & $\$ 23.10$ & $\$ 25.41$ & $\$ 27.951$ & $\$ 30.7461$ \\
\hline Shares assumed issued & 500,000 & 500,000 & 500,000 & 500,000 \\
\hline Shares assumed purchased & $\underline{608,268}$ & $\underline{518,665}$ & $\underline{440,327}$ & $\underline{371,945}$ \\
\hline Difference & $-108,268$ & $-18,665$ & $\overline{59,673}$ & 128,055 \\
\hline Incremental shares & 0 & 0 & 59,673 & 128,055 \\
\hline Actual shares outstanding & $\underline{10,000,000}$ & $\underline{10,000,000}$ & $\underline{10,000,000}$ & $\underline{10,000,000}$ \\
\hline Denominator & $\overline{10,000,000}$ & $\overline{10,000,000}$ & $\overline{10,059,673}$ & $\overline{10,128,055}$ \\
\hline Reported Diluted EPS & $\$ 2.22283$ & $\$ 2.45383$ & $\$ 2.69187$ & $\$ 2.94967$ \\
\hline $\begin{array}{l}\text { Panel B: Correct Comput } \\
\text { Proceeds Exclude Unrecog }\end{array}$ & $\begin{array}{l}\text { mployee Con } \\
\text { ompensation }\end{array}$ & $\begin{array}{l}\text { n Recognized C } \\
\text { asury Stock Pu }\end{array}$ & $\begin{array}{l}\text { Service Period } \\
\text { at End of Peri }\end{array}$ & nuity), \\
\hline & Year $x 1$ & Year x2 & Year x3 & Year $x 4$ \\
\hline Inc. before comp. exp. & & & & \\
\hline Compensation exp. & $\$ 23,100,000$ & $\$ 25,410,000$ & $\$ 27,951,000$ & $\$ 30,746,100$ \\
\hline Net Income - Numerator & $1,000,000$ & $1,000,000$ & $1,000,000$ & $1,000,000$ \\
\hline & $\overline{\$ 22,100,000}$ & $\overline{\$ 24,410,000}$ & $\overline{\$ 26,951,000}$ & $\overline{\$ 29,746,100}$ \\
\hline Proceeds: & & & & \\
\hline Exercise cash & $\$ 11,000,000$ & $\$ 11,000,000$ & $\$ 11,000,000$ & $\$ 11,000,000$ \\
\hline Unrecognized comp. & $\underline{0}$ & $\underline{0}$ & $\underline{0}$ & $\underline{0}$ \\
\hline Total proceeds & $\$ 11,000,000$ & $\$ 11,000,000$ & $\$ 11,000,000$ & $\$ 11,000,000$ \\
\hline Total proceeds/sh. & $\$ 22.00$ & $\$ 22.00$ & $\$ 22.000$ & $\$ 22.0000$ \\
\hline Treasury purchase price/sh. & $\$ 24.20$ & $\$ 26.62$ & $\$ 29.282$ & $\$ 32.2102$ \\
\hline Shares assumed issued & $500,000.000$ & $500,000.000$ & $500,000.000$ & $500,000.000$ \\
\hline Shares assumed purchased & $\underline{454,545.454}$ & $\underline{413,223.141}$ & $\underline{375,657.401}$ & $\underline{341,506.728}$ \\
\hline Difference & $45,454.545$ & $86,776.859$ & $\overline{124,342.600}$ & $\overline{158,493.272}$ \\
\hline Incremental shares & $45,454.545$ & $86,776.859$ & $124,342.600$ & $158,493.272$ \\
\hline Actual shares outstanding & $\underline{10,000,000.00}$ & $\underline{10,000,000.00}$ & $\underline{10,000,000.00}$ & $10,000,000.00$ \\
\hline Denominator & $\overline{10,045,454.54}$ & $\overline{10,086,776.86}$ & $\overline{10,124,342.60}$ & $\overline{10,158,493.27}$ \\
\hline Correct Diluted EPS & $\$ 2.20$ & $\$ 2.42$ & $\$ 2.662$ & $\$ 2.9282$ \\
\hline
\end{tabular}

Note also that Table 2 (Panel B) provides the same numerator and denominator amounts that appear in Table 1 (Panel C) where the employee was compensated directly through stock issuance at the beginning of each year. Achieving this equivalence is the objective of accounting for employee stock options and reporting related EPS amounts as stated by the FASB: “....Recognition of the compensation cost resulting from awards of employee share options is no different from the accounting for other transactions in which use of the consideration received for issuing equity instruments reduces reported earnings, and the related instruments increase either actual or potential common shares outstanding.,"12

\section{CONCLUSION AND RECOMMENDATIONS}

The combination of treating the employee service as provided ratably over the service period (as an annuity), excluding unrecognized compensation from the assumed exercise proceeds, and assuming treasury shares

\footnotetext{
${ }^{12}$ Statement of Financial Accounting Standards No. 123, Revised (December 2004) Paragraph 28B.
} 
are purchased at the higher year-end price results in presenting correct known amounts of diluted EPS in the case of employee stock options - see Table 2 (Panel B). As can be seen from Table 2 (Panel A), calculated EPS is consistently overstated under US GAAP and IFRS. These results confirm the findings of Doran (2005 and 2008) regarding the amount of employee compensation that should be recognized and the need to assume treasury shares are purchased at the higher year-end price. The contribution of this study is the finding that unrecognized employee compensation should not be included in the assumed proceeds from the assumed exercise of employee stock options when applying the treasury stock method.

In 2008 the FASB and the IASB considered making changes to reported EPS. Regarding stock options, both boards proposed using the end of period price rather than the average for the period price for determining the assumed number of treasury shares acquired. ${ }^{13,14}$ Because they subsequently put their EPS projects "on the back burner," to date neither board has formally made the change. The results of this study and those of Doran (2005 and 2008) should be useful to the FASB and the IASB if and when they revisit their EPS projects. In the case of employee stock options, diluted EPS should be computed where: 1) Employee compensation is appropriately treated as an annuity - incurred periodically over time, 2) Shares purchased for the treasury are assumed acquired at the higher year-end price, and 3) The proceeds from assumed stock option exercise should not include unrecognized compensation.

\section{AUTHOR INFORMATION}

David T. Doran. Upon receiving his undergraduate degree with a major in accounting from Robert Morris University, David T. Doran was employed by the "big eight" public accounting firm of Coopers \& Lybrand. He is currently licensed to practice as a CPA in Pennsylvania. Professor Doran earned his MBA and PhD degrees from the University of Pittsburgh and has been teaching at Penn State - Erie since 1989. His primary research interests are in the financial accounting area, which is consistent with his main teaching responsibilities. David T. Doran, Ph.D., Associate Professor of Accounting, Black School of Business, Penn State - Erie, 5101 Jordan Rd., Erie, PA 16563, USA. E-mail: dtd1@psu.edu

\section{REFERENCES}

1. Financial Accounting Standards Board (2013). Accounting Standards Codification.

2. Doran, D.T. (2005). Employee Stock Options and Diluted EPS. Journal of Business and Economics Research, 3(11) 51-56.

3. Doran, D.T. (2008). Employee Stock Options and Diluted EPS: An Extension. International Business and Economics Research Journal, 7(2) 25-31.

4. Financial Accounting Standards Board (2008, August). Earnings per Share. Proposed Statement of Financial Accounting Standards.

5. Financial Accounting Standards Board (1997, February). Earnings per Share. Statement of Financial Accounting Standards No. 128.

6. Financial Accounting Standards Board, Statement of Financial Accounting Standards No. 123 (revised 2004), "Share-Based Payment", December 2004.

7. International Accounting Standards Board (2008, August). Simplifying Earnings per Share. Exposure Draft: Proposed Amendment to IAS No. 33.

8. International Accounting Standards Board (2013). Share Based Payment. International Financial Reporting Standard No. 2.

9. International Accounting Standards Board (2013). Earnings per Share. International Accounting Standard No. 33 .

10. International Accounting Standards Board (2013). International Financial Reporting Standards. Official Pronouncements.

11. Nikolai, Bazley and Jones (2010). Intermediate Accounting $11^{\text {th }}$ Ed. South-Western, Cengage Learning.

\footnotetext{
${ }^{13}$ Proposed Statement of Financial Accounting Standards, an amendment to FASB Statement No. 128 (August 2008) Paragraph 9.

${ }^{14}$ Exposure Draft, Proposed amendments to IAS 33 (August 2008) Paragraph No. 46.
} 


\section{NOTES}

